\title{
Discussion on Direction of the Art Education Reform
}

\author{
Bianling Zhang \\ School of Art and Design \\ Huanghe Science and Technology College \\ Zhengzhou, China \\ e-mail: 24196102@qq.com
}

\begin{abstract}
If art education adapts to the requirements of modernization, it must serve the commodity economy and scientific modernization and make due contribution to material civilization construction while serving the spiritual civilization construction of our country. We must change the idea of art and art education thoroughly and break the old teaching system that bases on modeling and improves the art appreciation and painting skills of students, setting up teaching system which bases on all kinds of basic expressional languages, improving imagery thinking and creativity as the means, for the purpose of improving national consciousness and level of design. Only in this way can the reform of art call meaningful reform and the reform of art that truly adapts to modernization. Because now our country is not in badly need of artists who indulge in self-admiration and talk without any action but improving the level of design and practical art of people throughout the country.
\end{abstract}

\section{Keywords-art education; nature; direction}

\section{INTRODUCTION}

As a product of the spirit civilization of human beings, art is an important part of human culture. This is because after humans have art, civilization comes into being and then culture appears. Art is a kind of the most advanced cultural form producing in the process that humans know the world. It goes with the progress of human history from beginning to end and undertakes the mission of civilization constructions.

Although art in primitive times had close relationship with witchcraft activities, as an art education passing on technical skills, art had rules of itself. In the process of survival, human beings not only use their wisdom to create life and cultivate aesthetic judgment in labor, but most fortunately, humans understand the special position that the transmission of skills and experience of predecessors occupies in life. In the process of continuation of experience and technology, craftsmen have cultivated artistic talents more excellent than predecessors as well. The initiation of experience is the continuity of human survival and development as well as the succession of experience in art activities in the early stage of human beings. Thus art education shows specific social values.

Art education is a kind of social behavior that educators cultivate the educated to form the integral understanding of art and creative ability organically through art means. For ones who accept art education, the result of their expectation is different from their learning. One result is becoming an artist, and the other result is accepting cultural education of art, and the key point is to accept education of art appreciation. It forms the fact that art education has specific education features and action structures that must train out producers and consumers of art. In other words, art education has something in common with general education and it has personality as well. The nature of art education is sublimation of individuality above the unity of humanity, sociality, productivity and internationalism cultivated by essential system of general education. The nature of general education is a logical starting point studying art education. The development of art education promotes the development of overall education in particular society as well. The so-call nature of art education is the most fundamental essential regularity that art education differs from other things. The nature of art education is a three-dimensional structural system, including character of spatial aesthetic education (namely education of acquisition of art inspiration, education character of the raw feeling of art and the training of modeling feeling ability), character of enlightenment, induction and creativity education (namely education of effective vent of emotion, performance practice of charming beauty) and character of emotional enjoyment education.

\section{Character of Spatial Aesthetic EducAtion of ART EDUCATION}

The character of spatial aesthetic education of art education is determined by the spatiality of two-dimension or three-dimension and visual intuition of art itself. In the process of art education, except for the general education features of practical education, first and foremost, we must explain the importance and meaning of accepting effective capture of art inspiration, strengthening the direct feelings of art forms and the fostering and training of the sensory capacity of modeling for art learners. No matter professional or non-professional art education, it is important to educate students the awareness and ability of raw feelings related to art. That is to say, art educators should trigger the inner strength of students actively, stimulate students to generate positive feelings, experience and reflection for their living environment, facilitating students to accumulate experience of themselves and external object, choose the reason and ways of survival to acquire enterprising confidence and the power of art creation by using specific thought and artistic epistemology of art. Secondly, we should guide and train 
students effectively to form perceptual knowledge of art forms and intensify training students' feelings of art modeling. For example, we can ask students to portray "a melodious melody in the wind", "a timid rogue with a shudder of horror" with the technique of expression of sketch. In the behavior of art education, education character of space raw feeling is the primary nature of art education. It is also the sublimation and materialization of the nature of educating person of general education. Both art educators and art learners should fully know this character. Only in this way can they find the effective point of penetration of art learning, study and appreciation thoroughly by themselves.

\section{CHARACTER OF ENLIGHTENMENT, INDUCTION AND CREATIVITY EDUCATION OF ART EDUCATION}

The character of enlightenment, induction and creativity education of art education is determined by characteristic of visual implementation of art itself to pursue great aesthetic value. As an indispensable member in the family of art, one of the specific characters of fine arts is to pursue the visual implementation of beauty in the activity of extreme imagination. Robin George Collingwood once wrote in the New Discussion on Philosophy of Art: "Art is imagination and imagination is activity. Imagination should not simply let continuous images flow through the heart randomly. One should try hard to imagine and engage in the imagination. Just like a person can imagine any other things, he can also imagine at will. Therefore, although a person can imagine without any difficulty, in order to try hard to imagine better, he should imagine better from integral and long-range opinions." In art education, how to "think better" after motivating students' rich imagination that art needs? One important thing is that art educators should timely and effectively enlighten and lead students to strive to explore the educational method that students externalize and express their rich imagination. In other words, art educators should exert themselves to enlighten and induce students to vent and show the particular art inspiration and internal mind and art emotion and stimulate students to present the beauty of the most attractive in continuous practice of art creation effectively. Even though some artists say that art cannot be taught and practice has proved that real art cannot be taught out. It doesn't mean that art educators cannot do anything or helpless in front of art learners. This indicates that it requires art educators to explore and seek out scientific, artistic and effective educational ways that are unique and easy to enlighten and trigger the creation of students. It is difficult to become a real art educator always having good methods of art education.

\section{CHARACTER OF EMOTIONAL ENJOYMENT EDUCATION OF ART EDUCATION}

The character of emotional enjoyment education of art education is determined by the externalization implementation of behavior of the art creation. When appreciators are in face of the specific work of art that congeals inner emotional heart of painter, whether they can have unique aesthetic feeling is a way to measure the level that aesthetic functions of work of art reaches. This only shows the problem that whether the work of art has the inner attractive beauty to stimulate the appreciators. On the other hand, a piece of excellent work of art cannot be appreciated by all the viewers in front of it. The viewers themselves have the problem of higher or lower level of art appreciation. Therefore, as individuals in the process of continuous socialization, we should take it for granted to accept certain and effective art education, especially accepting certain education of art concept and artistic appreciation. This is also the main content that non art education implements except for the educational content that professional art education should attach importance to and emphasize. Just as Reed said, "The number of people receiving the education of art appreciation should be increased widely. Except for those who are slow-witted and have mental disturbance to accept art education, all the people should take part in the training of art appreciation. Because common sense and psychology tell us that the impulse of aesthetic appreciation owned by children throughout the world all the time only exists on the so-called ones who accept education." So in the whole behavior of art education, how to effectively train and cultivate students to acquire certain ability to enjoy the beauty of art is an important task and content, thereby showing the special nature of art education. Effective appreciation and grasp of typical artistic beauty such as works of art cannot proceed only through mastering certain rational knowledge. The process of works of art appreciation needs appreciators to have fairly strong perceptual intuition ability to perceive, judge and imagine the attractive beauty, excellence and defects of works of art, for example, "a student maybe know all the facts (dates of birth and death of artists, the demarcation of the name and process of art, even the psychology of art), but when he sees a piece of work of art, he cannot recognize it and cannot distinguish the aesthetic advantages and disadvantages in a series of works of art." It shows that the ability to enjoy the beauty of art needs effective education and training.

In conclusion, only understanding fully about the specific qualitative regularity of art education can we better carry out the art education, a kind of special socialized behavior of education. However, now there are few persons in our country pay attention to do research on the nature of art education, then where is the fundamental orientation of the reform of art education?

If art education adapts to the requirements of modernization, it must serve the commodity economy and scientific modernization and make due contribution to material civilization construction while serving the spiritual civilization construction of our country. We must change the idea of art and art education thoroughly and break the old teaching system that bases on modeling and improves the art appreciation and painting skills of students, setting up teaching system which bases on all kinds of basic languages expression, improving imagery thinking and creativity as the means, for the purpose of improving national consciousness and level of design. Only in this way can the reform of art call meaningful reform and the reform of art that truly adapts to modernization. Because now our country is not in badly need of artists who indulge in self-admiration and talk 
without any action but improving the level of design and practical art of people throughout the country.

Looking from history, if art leaves science and the development of productivity and the social material civilization and enters the tower of ivory of pure art, it will go into the situation of empty and absurd and become a trick that a small part of people fool with skills and character and then make fool of audience. If we say the combination of art and science in western history plays the prelude of sonorous modern civilization, then the design art of Bauhaus blows the song of victory of modern industrial civilization. Then in Chinese painting, the leisurely and carefree mood of literati and scholar-officials who indulge in self-admiration, show off literary skills and mystify deliberately plays a negative mournful song, because the interest of the most excellent intellectuals in the country is not based on science, but on the pure game of words and the mysterious theory. Then what the nation lefts except for play? Western art is creating life but Chinese life is escaping from life. To be fair, from the point of view of pure art, Chinese art is as good as the art in any other country, and its mysterious theory, profound skills and miscellaneous kind take the lead in the world. But from the point of view of historical development, Chinese art doesn't have beneficial effects on the development of the nation, and it is just a kind of game for men of literature and writing to entertain themselves or a handkerchief with tears full of anger and sadness of the sorehead poets. In the process of escaping from reality, Chinese painting goes to an almost perfect elegance. If an art reaches the condition that it is so abstruse that only several people can enjoy and so elegant that the public feel at a loss, then it is the time when the art reaches the dead end. However, this is not to deny traditional art thoroughly and abandon the vital and excellent constituent part of traditional and foreign art. On the contrary, we have to inherit and carry forward the quintessence of those human cultures. But the problem is: Is there a need to let all the people to master and understand this kind of pure artistic fine arts full of pure appreciation? How many painters and connoisseurs that China need? The training of the theory and techniques of art cannot take effect in a short duration of time and there are few class hours of art lesson. Besides, skill training needs special classrooms and teaching aids and many schools don't have these things. So it is impossible to have better teaching effect. In addition, the learning of art needs certain talents. Without keen insight of modeling, it is hard for the comprehension of skill training and theory to achieve high grades. Therefore, it is really a kind of waste to let all the students learn art in conventional sense. By the way, there is a reality that students' education does not fit him for a certain job in the education of advanced art, many graduates majoring in Painting and Chinese Painting turn to applied art such as decoration etc. after stepping into society. Isn't it also well proved the embarrassed situation of art teaching?

\section{CONCLUSION}

This shows that art education must be reformed and meet the needs of the construction of modernization and combine with scientific and technological productive forces to play a due role in the construction of material civilization of our country. And this kind of reform must be the reform of art and the concept of art education, completely breaking the art teaching system dominated by aesthetic appreciation and based on drawing skills. We must let art give full play to its advantages and move towards refulgence in the process of returning to real life instead moving towards loneliness in perfect. Then how to re-understand the meaning of art and redefine the meaning of art education? I think art is a kind of science to beautify life, create life and design life and it is a kind of creative labor that human beings endow matter with glorious ideals while creating matter. Art is not only a kind of material mode of production but also a kind of ideological productive mode. When it meets the material needs of humans, it meets the spiritual needs of humans as well. The so-called artists are those who endow his own material products with knowledge, personality and ideals of themselves to let others move, love and use. Under this premise, art is divided into pure art derived from it. Its significance is to let people get mental satisfaction and sublimation in more abstract and theoretical aesthetic appreciation and open up a more pure and ideal world for the spiritual world of human beings. The meaning of art education is: We can improve the design consciousness and creativity of the whole nation, provide a good foundation for the modernization construction of the country and create advantageous conditions for the rapid development of the nation through learning design and life, design and civilization, design and science and technology and design and aesthetic appreciation, through training imagination, creativity and imagery thinking and through learning and grasping a variety of design language. Meanwhile, we should take the appreciation of traditional and foreign art and the improvement of skills into account and select and cultivate talents with painting talent to enter the higher lever to ensure the inheritance and development of outstanding achievements of traditional and foreign art. The understanding of art should not be confined to art and artists. We also should know the role and function of art in society. The value of art is to promote the profound understanding of culture and social presence, using situated learning to replace the learning of art history of the straight line form. It is widely believed that using the method of situated learning to learn art history and other cultural and art fields related to art can know the mutual relation between art and society and eliminate the dividing line of noble art and lower art. The combination of pluralism and diversification can produce the works of diversity and multimedia.

In a word, art education at school should pay more attention to the relation between art and culture and society. Designing a kind of open art curriculum that can be adopted and extended becomes the focus of art education reform of various countries in the world.

\section{REFERENCES}

[1] Pang Xueguang. Two Criticism on the Practice of Moral Education, selected from Education and Scientific Research of Shanghai, Issue 11 (1999) 
[2] Selected from Art Curriculum Standard of Full-Time Compulsory Education, Beijing Normal University Press, June, 2003

[3] Selected from Art Curriculum Standard of General Senior High School, People's Education Press, April, 2003

[4] Chen Wenbin, Hu Jiyuan, Shen Zhengyuan. Simple Analysis of the Theoretical Framework of Modernization of Artistic Education, selected from Primary and Secondary School Education of Foreign Countries, Issue 2 (1998)

[5] Zhou Guansheng. The Primary Exploration of Contemporary Art Education in the United States, selected from the Primary and Secondary School Education of Foreign Countries, Issue 3 (1998).

[6] Hu Jiyuan, Shen Zhengyuan, Wang Bingzhang. The Characteristics and Revelation of Art Education Reform in American Middle School, selected from the Primary and Secondary School Education of Foreign Countries, Issue 5 (2000).

[7] Qian Chuxi. The Review on the Art Education in the 20th Century and Discussion on Development Direction in the 21st Century, selected from Chinese Art Education, Issue 4 (1999). 